\title{
Pengaruh Current Ratio, Debt to Equity Ratio, Return on Asset dan Asset Growth terhadap Beta Saham pada Perusahaan Real Estate dan Property di Bursa Efek Indonesia
}

\author{
Diah Ayu Shoviana Ranti ${ }^{1)}$ \\ Sekolah Tinggi Ilmu Ekonomi YPPI Rembang \\ Damayanti $^{2)}$ \\ Sekolah Tinggi Ilmu Ekonomi YPPI Rembang \\ E-mail: shoviana.ranti@gmail.com ${ }^{1)}$ \\ E-mail:damayanti_rahmania@yahoo.co.id ${ }^{2)}$
}

\begin{abstract}
Abstrak
Tujuan penelitian yang dilakukan adalah untuk membuktikan dan menjelaskan pengaruh current ratio, debt to equity ratio, return on asset dan asset growth terhadap beta saham pada perusahaan real estate dan property di Bursa Efek Indonesia. Populasi dari penelitian ini adalah perusahaan real estate dan property di Bursa Efek Indonesia tahun 2014-2018. Pengambilan sampel dalam penelitian yang dilakukan menggunakan teknik purposive sampling yaitu pengambilan sampel dengan kriteria tertentu dan diperoleh sebanyak 10 perusahaan selama 5 tahun, sehingga diperoleh 50 observasi. Analisis data yang digunakan dalam penelitian yang dilakukan adalan teknik analisis regresi linier berganda dengan menggunakan uji t. Berdasarkan hasil penelitian yang dilakukan menunjukkan bahwa current ratio berpengaruh negatif tidak signifikan terhadap beta saham, debt to equity ratio dan return on asset berpengaruh positif signifikan terhadap beta saham sedangkan asset growth berpengaruh positif tidak signifikan terhadap beta saham. Hasil pengujian koefisien determinasi menunjukkan nilai 0,239 yang artinya bahwa variabel current ratio, debt to equity ratio, return on asset dan asset growth mampu menjelaskan variabel beta saham sebesar 23,9\% sedangkan 76,1\% kemungkinan dijelaskan oleh faktor lain di luar model penelitian ini.
\end{abstract}

Kata Kunci: current ratio, debt to equity ratio, return on asset, asset growth dan beta saham.

\section{Pendahuluan}

Pasar modal merupakan tempat pertemuan antara pihak yang kelebihan dana dengan pihak yang membutuhkan dana dengan cara memperjualbelikan sekuritas yang umumnya memiliki umur lebih dari satu tahun, seperti saham dan obligasi (Hartono, 2017:33). Pasar modal menciptakan alokasi dana yang efisien karena dengan adanya pasar modal maka pihak yang kelebihan dana (investor) dapat memilih alternatif investasi yang memberikan return yang paling optimal. Pasar modal dipandang sebagai salah satu sarana yang efektif untuk mempercepat pembangunan suatu negara, karena berfungsi sebagai sarana bagi pendanaan usaha untuk mendapatkan dana dari investor. Investasi merupakan penundaaan konsumsi sekarang untuk dimasukkan ke aktiva produktif selama periode tertentu (Hartono, 2017:5). Tujuan investor berinvestasi beraneka ragam mulai dari untuk memperoleh keuntungan, memenuhi kebutuhan hidup maupun memperoleh return dari investasi itu sendiri. Investor 


\section{Diah Ayu Shoviana Ranti, Damayanti}

pasti memperhitungkan tingkat keuntungan yang diharapkan dan risiko yang dihadapi atas investasi di pasar modal. Terdapat hubungan positif antara risiko (risk) dan tingkat keuntungan (return). Semakin tinggi risiko (risk) akan semakin tinggi tingkat keuntungan (return) yang diharapkan (Hanafi dan Halim, 2016:297). Risiko investasi di pasar modal dapat dibedakan menjadi dua, yaitu risiko tidak sistematis (unsystematic risk) dan risiko sistematis (systematic risk). Risiko tidak sistematis sering diabaikan karena sifatnya dapat dihilangkan dengan cara diversifikasi misalnya kerusakan mesin perusahaan, aksi pemogokan pegawai, dan lain-lain. Risiko sistematis berasal dari luar perusahaan sehingga investor tidak mampu menghilangkannya dengan diversifikasi sekuritas maupun portofolio misalnya terjadi inflasi, krisis moneter, tingkat suku bunga (Hartono, 2017:356).

Risiko sistematis disebut dengan beta, karena beta merupakan pengukur dari risiko sistematis suatu sekuritas atau portofolio relatif terhadap risiko pasar. Volatilitas adalah fluktuasi dari return suatu sekuritas atau return portofolio dalam suatu periode tertentu. Beta sekuritas ke-i mengukur volatilitas return sekuritas ke-i dengan return pasar (Hartono, 2017:464). Penelitian tentang faktor-faktor yang dapat memprediksi beta saham atau risiko sistematis merupakan hal yang menarik untuk dilakukan karena sifat dari risiko yang selalu melekat pada setiap investasi. Beberapa penelitian terdahulu banyak yang meneliti tentang faktor yang mempengaruhi beta saham antara lain current ratio, debt to equity ratio, return on asset dan asset growth.

Penelitian tentang pengaruh current ratio terhadap beta saham diteliti oleh Soeroso (2013) dalam Yulia dan Pohan (2015) menunjukkan bahwa current ratio berpengaruh negatif signifikan terhadap beta saham. Hasil tersebut didukung oleh penelitian Suseno (2009) dalam Aji dan Prasetiono (2015) bahwa current ratio juga berpengaruh negatif signifikan terhadap beta saham. Hasil tersebut bertolak belakang dengan penelitian Jazuli dan Witiastuti (2016) yang menunjukkan current ratio berpengaruh positif signifikan terhadap beta saham. Penelitian Hermawan (2018) dan Laraswati, dkk (2018) menunjukkan current ratio berpengaruh positif tidak signifikan terhadap beta saham. Penelitian tentang pengaruh debt to equity ratio terhadap beta saham diteliti oleh Kurniawan dan Mawardi (2018), Zeinora (2015), Laraswati, dkk (2018) menunjukkan bahwa debt to equity ratio berpengaruh positif signifikan terhadap beta saham. Hasil tersebut bertolak belakang dengan penelitian Jazuli dan Witiastuti (2016) menunjukkan bahwa debt to equity ratio berpengaruh negatif tidak signifikan terhadap beta saham. Penelitian Priyanto (2017) menunjukkan bahwa debt to equity ratio berpengaruh positif tidak signifikan terhadap beta saham. Penelitian tentang pengaruh return on asset terhadap beta saham diteliti oleh Oktodinata (2015) menunjukkan bahwa return on asset berpengaruh positif signifikan terhadap beta saham. Hasil tersebut bertolak belakang dengan penelitian Laraswati, dkk (2018) menunjukkan bahwa return on asset berpengaruh positif tidak signifikan terhadap beta saham. Penelitian Kurniawan dan Mawardi (2018) menunjukkan bahwa return on asset berpengaruh negatif tidak signifikan. Penelitian tentang pengaruh asset growth terhadap beta saham diteliti oleh Aji dan Prasetiono (2015), Chen (2014) dalam Laraswati, dkk (2018) menunjukkan bahwa asset growth berpengaruh positif signifikan terhadap beta saham. Hasil tersebut bertolak belakang dengan penelitian Jazuli dan Witiastuti (2016) dan Hermawan (2018) menunjukkan bahwa asset growth berpengaruh negatif signifikan terhadap beta saham. Hasil dari semua penelitian terdahulu terdapat perbedaan hasil penelitian (research gap) karena perbedaan dalam pengukuran variabel dan populasi penelitian sehingga penelitian yang dilakukan akan menguji kembali variabel current ratio, debt to equity ratio (DER), return on asset (ROA) dan asset growth terhadap beta saham perusahaan property dan real estate di Bursa Efek Indonesia. 


\section{Diah Ayu Shoviana Ranti, Damayanti}

Objek penelitian ini adalah perusahaan real estate dan property yang terdaftar di Bursa Efek Indonesia, pemilihan perusahaan real estate dan property karena memiliki prospek yang cerah dimasa yang akan datang dengan melihat pertumbuhan penduduk yang semakin banyak apartemen dan mall yang sering dijumpai sehingga investor tertarik menginvestasikan dananya di sektor property. Investasi di property bersifat jangka panjang dan pertumbuhannya sangat sensitif terhadap indikator makro ekonomi seperti pertumbuhan ekonomi, laju inflasi dan tingkat suku bunga. Sektor real estate dan property adalah salah satu sektor yang mempunyai tingkat volatilitas tinggi mencapai $62,24 \%$ daripada sektor lainnya seperti sektor mining $(62,23 \%)$ dan sektor agriculture $(39,04 \%)$. Harga saham pada pasar yang cepat naik dan turun ini cenderung memiliki tingkat risiko yang lebih tinggi sehingga meneliti tentang beta saham di sektor property dapat memberi manfaat bagi investor yang berkepentingan.

Perusahaan real estate dan property yang terdaftar di Bursa Efek Indonesia periode 2014-2018, rata-rata banyak yang mengalami perubahan beta saham fluktuasi. Berdasarkan Tabel data beta saham menunjukkan bahwa perusahaan real estate dan property yang terdaftar di Bursa Efek Indonesia mengalami perubahan beta yang berfluktuasi sebanyak 23 perusahaan dan 3 perusahaan mengalami penurunan. Terdapat 22 perusahaan tidak konsisten melaporkan data beta saham. Sesuai latar belakang di atas maka peneliti mengambil judul "Pengaruh Current Ratio, Debt to Equity Ratio, Return on Asset dan Asset Growth terhadap Beta Saham pada Perusahaan Real Estate dan Property di Bursa Efek Indonesia”.

\section{A. Rumusan Masalah}

Berdasarkan latar belakang di atas maka dapat diambil rumusan masalah yaitu bagaimana pengaruh current ratio, debt to equity ratio, return on asset dan asset growth terhadap beta saham pada perusahaan real estate dan property di Bursa Efek Indonesia.

\section{B. Tujuan Penelitian}

Berdasarkan rumusan masalah yang telah dirumuskan, maka tujuan penelitian ini adalah untuk menguji dan menjelaskan pengaruh current ratio, debt to equity ratio, return on asset dan asset growth terhadap beta saham pada perusahaan real estate dan property di Bursa Efek Indonesia.

\section{Landasan Teori}

\section{Risk dan Return}

Investor pada umumnya melihat dua hal dalam membuat sebuah keputusan berinvestasi yaitu pendapatan (return) dan risiko (risk). Return adalah keuntungan yang diperoleh dari aktivitas investasi yang dilakukan. Risiko merupakan besarnya penyimpangan antara tingkat pengembalian yang diharapkan (expected return) dengan tingkat pengembalian aktual (actual return). Return dan risk merupakan dua hal yang tidak terpisahkan, karena pertimbangan suatu investasi merupakan trade-off dari kedua faktor tersebut (Husnan dan Enny, 1993 dalam Jazuli dan Witiastuti, 2016). Terdapat hubungan positif antara risiko dengan tingkat keuntungan (return). Semakin tinggi risiko akan semakin tinggi tingkat keuntungan (return) yang diharapkan (Hanafi dan Halim, 2016:297). 


\section{Diah Ayu Shoviana Ranti, Damayanti}

Menurut Hartono (2017:356) pada saat berinvestasi dikenal dua macam risiko yaitu risiko sistematis yaitu risiko yang tidak dapat dikurangi dengan cara diversifikasi (nondiversifiable risk). Risiko ini adalah risiko paling minimum yang harus diambil investor dari investasi/portofolio yang dilakukannya seperti pasar lesu (bearish), inflasi, resesi, krisis moneter (1), risiko tidak sistematis yaitu risiko yang melekat pada perusahaan dan dapat dikurangi melalui diversifikasi seperti kelalaian manajer, kerugian usaha, pemogokan karyawan, dan lain-lain (2).

\section{Capital Asset Pricing Model (CAPM)}

Capital asset pricing model (CAPM) merupakan model untuk menentukan harga suatu aset. CAPM mendasarkan diri pada tingkat keuntungan yang disyaratkan oleh pemodal untuk suatu saham akan dipengaruhi oleh risiko saham tersebut pada kondisi pasar yang seimbang (Ekuilibrum) (Hartono, 2017:577). Risiko bukan diartikan deviasi standart tingkat keuntungan, tetapi diukur dengan beta $(=\beta)$. Penggunaan parameter ini konsisten dengan teori portofolio yang mengatakan bahwa apabila pemilik modal melakukan diversifikasi dengan baik, maka pengukur risiko adalah sumbangan risiko dari tambahan saham dalam portofolio pasar yaitu beta.

Model CAPM merupakan pengembangan teori portofolio yang dikemukakan oleh Markowitz dengan risiko sistematis dan risiko tidak sistematis. Model indeks tunggal didasarkan pada pengamatan bahwa harga dari suatu sekuritas berfluktuasi searah dengan indeks harga pasar. Saham cenderung mengalami kenaikan harga jika indeks harga saham naik dan jika indeks harga saham turun kebanyakan saham mengalami penurunan harga. Return dari sekuritas mungkin berkorelasi karena adanya reaksi umum (common response) terhadap perubahan-perubahan nilai pasar (Hartono, 2017:427).

\section{Beta Saham}

Beta merupakan pengukur risiko sistematis (systematic risk) dari suatu sekuritas atau portofolio relatif terhadap risiko pasar. Volatilitas dapat didefinisikan sebagai fluktuasi dari return suatu sekuritas atau portofolio dalam suatu periode waktu tertentu. Beta pada dasarnya menggambarkan seberapa peka suatu sekuritas terhadap perubahan pasar. Semakin tinggi beta suatu sekuritas atau portofolio maka semakin sensitif terhadap perubahan pasar (Hartono, 2017:464). Beta bernilai lebih dari satu yaitu umumnya lebih agresif dari pasar, pada saat harga naik dengan cepat maka akan melebihi kenaikan pasar atau indeks harga saham gabungan (IHSG). Pada saat harga turun, harganya akan turun lebih cepat dari pasar. Beta bernilai sama dengan satu artinya mengikuti arus pasar yaitu jika pasar naik, saham tersebut mengalami kenaikan yang sama dengan pasar dan sebaliknya. Beta bernilai kurang dari satu artinya begerak lebih lambat dari pasar yaitu jika pasar naik, saham akan mengalami kenaikan namun lebih rendah dari kenaikan pasar (Hartono, 2017:465).

\section{Current Ratio}

Current ratio merupakan rasio yang digunakan untuk mengukur kemampuan perusahaan dalam memenuhi kewajiban jangka pendeknya yang segera jatuh tempo dengan menggunakan total aset lancar yang tersedia (Hery, 2016:152). Perusahaan harus terusmenerus memantau hubungan antara besarnya kewajiban lancar dengan aset lancar. Perusahaan yang memilki rasio lancar yang kecil mengindikasikan bahwa perusahaan 
tersebut memiliki modal kerja (aset lancar) yang sedikit untuk membayar kewajiban jangka pendeknya. Perusahaan memiliki rasio lancar yang tinggi, belum tentu perusahaan tersebut dikatakan baik karena rasio lancar yang tinggi dapat terjadi karena kurang efektifnya manajemen kas dan persediaan.

\section{Debt to Equity Ratio (DER)}

Debt to equity ratio (DER) adalah rasio yang digunakan untuk mengetahui bagian dari setiap rupiah ekuitas dana yang dijadikan jaminan untuk keseluruhan utang (Kasmir, 2018:158). Rasio utang mengidentifikasi seberapa besar perusahaan terbebani oleh utang. Rasio utang terhadap ekuitas yang tinggi mengidentifikasi bahwa perusahaan mungkin kelebihan utang (over-leverage) dan harus mencari jalan untuk mengurangi utang tersebut. Penggunaan utang yang relatif tinggi akan menimbulkan biaya tetap berupa beban bunga dan angsuran pokok pinjaman yang harus dibayar, semakin besar biaya tetap berakibat menurunnya laba perusahaan. Hal ini akan berdampak pada penurunan dividen yang akan meningkatkan risiko investasi (Riyanto, 1995 dalam Jazuli dan Witiastuti, 2016).

\section{Return on Asset (ROA)}

Rasio profitabilitas diproksikan dengan return on asset yaitu rasio yang mengukur seberapa besar perusahaan dapat memanfaatkan aktiva yang dimiliki untuk menghasilkan keuntungan bagi perusahaan (Purbawisesa dan Sampurno, 2016). Return on asset (ROA) digunakan untuk mengukur seberapa besar jumlah laba bersih yang akan dihasilkan dari setiap rupiah dana yang tertanam dalam total aset. Semakin tinggi hasil pengembalian atas aset berarti semakin tinggi pula jumlah laba bersih yang dihasilkan dari setiap rupiah dana yang tertanam dalam total aset dan sebaliknya (Hery, 2016:193). Return on asset (ROA) tinggi, maka tingkat pengembalian (return) yang diharapkan juga tinggi. Semakin tinggi return yang diperoleh maka semakin tinggi pula kemungkinan tingkat risiko yang dihadapi (Laraswati, dkk, 2018).

\section{Asset Growth}

Asset growth merupakan pengukur seberapa besar kemampuan aset perusahaan dalam mempertahankan posisinya di dalam industri dan dalam perkembangan ekonomi secara umum (Fahmi, 2011 dalam Priyanto, 2017). Asset growth menunjukkan tingkat pertumbuhan perusahaan untuk menghasilkan pendapatan yang lebih tinggi (Takarini, 2003 dalam Hermawan, 2018). Variabel pertumbuhan aktiva (asset growth) didefinisikan sebagai perubahan tahunan dari total aktiva. Variabel asset growth diprediksi mempunyai hubungan positif dengan beta.

\section{Pengembangan Hipotesis}

\section{Pengaruh Current Ratio terhadap Beta Saham}

Current ratio merupakan rasio yang digunakan untuk mengukur kemampuan perusahaan dalam memenuhi kewajiban jangka pendeknya yang segera jatuh tempo (Hery, 2016:152). Current ratio yang tinggi menunjukkan bahwa perusahaan memiliki kemampuan untuk melunasi kewajibannya yang telah jatuh tempo. Current ratio diprediksi mempunyai 


\section{Diah Ayu Shoviana Ranti, Damayanti}

hubungan negatif dengan beta karena secara rasional diketahui bahwa semakin likuid perusahaan (perusahaan memiliki kinerja baik dan memiliki peluang untuk bekerja sama dengan kreditor), semakin kecil juga risikonya (Hartono, 2017:480). Current ratio tinggi (current asset > current liabilities) maka semakin rendah risiko yang akan ditanggung investor jika akan berinvestasi pada sekuritas perusahaan tersebut. Hasil tersebut dibuktikan dengan penelitian Abdurahim (2003), Azmi (2014) dalam Jazuli dan Witiastuti (2016) menunjukkan adanya pengaruh negatif current ratio terhadap beta saham. Hasil diatas diperkuat dengan penelitian Kurniawan dan Mawardi (2018) bahwa current ratio berpengaruh terhadap beta saham. Berdasarkan penjelasan tersebut, maka hipotesis pertama yang diajukan adalah:

$\mathrm{H}_{1}$ : Diduga current ratio berpengaruh negatif signifikan terhadap beta saham.

\section{Pengaruh Debt to Equity Ratio terhadap Beta Saham}

Debt to equity ratio (DER) adalah rasio yang digunakan untuk mengetahui bagian dari setiap rupiah ekuitas dana yang dijadikan jaminan untuk keseluruhan utang (Kasmir, 2018:158). Rasio utang mengidentifikasi seberapa besar perusahaan terbebani oleh utang. Rasio utang terhadap ekuitas yang tinggi mengidentifikasi bahwa perusahaan mungkin kelebihan utang (over-leverage) dan harus mencari jalan untuk mengurangi utang tersebut. Penggunaan utang yang relatif tinggi akan menimbulkan biaya tetap berupa beban bunga dan angsuran pokok pinjaman yang harus dibayar, maka laba perusahaan akan turun. Hal ini berdampak pada penurunan dividen yang diterima investor akan meningkatkan risiko investasi (Riyanto, 1995 dalam Jazuli dan Witiastuti, 2016).

Leverage diprediksi mempunyai hubungan positif terhadap beta (Hartono, 2017:480). Gitman dan Zutter (2014) dalam Priyanto (2017) mengemukakan apabila leverage terlalu tinggi sementara jumlah aktiva tetap maka risiko kegagalan perusahaan untuk mengembalikan pinjaman tinggi dan sebaliknya. Hal tersebut dibuktikan dengan hasil penelitian yang dilakukan oleh Zeinora (2015) menunjukkan bahwa DER berpengaruh positif signifikan terhadap beta saham. Hasil penelitian dari Chandra (2013) dalam Priyanto (2017), Kurniawan dan Mawardi (2018) dan Laraswati, dkk (2018) juga menunjukkan bahwa DER berpengaruh positif signifikan terhadap beta saham. Berdasarkan penjelasan tersebut, maka hipotesis kedua yang diajukan adalah:

$\mathrm{H}_{2}$ : Diduga debt to equity ratio berpengaruh positif signifikan terhadap beta saham.

\section{Pengaruh Return on Asset terhadap Beta Saham}

Return on asset merupakan rasio yang menunjukkan seberapa besar kontribusi aset dalam menciptakan laba bersih. Semakin tinggi hasil pengembalian atas aset berarti semakin tinggi pula jumlah laba bersih yang dihasilkan dari setiap rupiah dana yang tertanam dalam total aset dan sebaliknya (Hery, 2016:193). Laraswati, dkk (2018) menyatakan return on asset adalah rasio yang mengukur kemampuan perusahaan dalam menghasilkan laba dari aktiva yang dipergunakan. Apabila return on asset meningkat, maka tingkat pengembalian (return) yang diharapkan juga akan meningkat. Semakin tinggi return yang diperoleh maka semakin tinggi pula kemungkinan tingkat risiko yang akan dihadapi.

Tingginya nilai ROA suatu perusahaan menunjukkan semakin besar keuntungan yang diperoleh perusahaan, keuntungan yang besar tersebut akan menarik minat dan harapan 


\section{Diah Ayu Shoviana Ranti, Damayanti}

investor untuk berinvestasi di perusahaan tersebut dengan tingkat pengembalian (return) yang tinggi. Semakin tinggi return maka semakin tinggi pula risk, sehingga diduga return on asset berpengaruh positif terhadap beta saham. Berdasarkan hasil penelitian Kustini dan Pratiwi (2011) dalam Priyanto (2017) menunjukkan bahwa return on asset berpengaruh positif terhadap beta saham. Hal tersebut didukung oleh hasil penelitian yang dilakukan Oktodinata (2015) variabel return on asset berpengaruh positif signifikan terhadap beta saham. Berdasarkan penjelasan tersebut, maka hipotesis ketiga yang diajukan adalah:

$\mathrm{H}_{3}$ : Diduga return on asset berpengaruh positif signifikan terhadap beta saham.

\section{Pengaruh Asset Growth terhadap Beta Saham}

Asset growth merupakan perubahan (tingkat pertumbuhan) tahunan dari aktiva total. Variabel asset growth diprediksi mempunyai hubungan positif dengan beta saham (Hartono, 2017:480). Tingkat pertumbuhan aset yang cepat menunjukkan bahwa perusahaan sedang melakukan ekspansi. Apabila ekspansi ini mengalami kegagalan maka akan meningkatkan beban perusahaan untuk menutup pengembalian biaya ekspansi yang akan menyebabkan nilai perusahaan itu menjadi kurang prospektif. Apabila kurang prospektif maka menyebabkan para investor menjual sahamnya di perusahaan tersebut karena minat dan harapan para pemodal turun, maka menyebabkan perubahan return saham yang besar yang berakibat pada beta saham perusahaan yang besar (Parmono, 2001 dalam Aji dan Prasetiono, 2015).

Kusuma (2016) menyatakan bahwa asset growth mempunyai pengaruh terhadap beta saham. Asset growth berpengaruh positif terhadap beta, pertumbuhan aktiva yang tinggi akan menimbulkan fluktuasi earnings perusahaan, sehingga perusahaan dengan tingkat pertumbuhan aktiva yang tinggi mempunyai dividend payout yang rendah. Dengan demikian berarti pertumbuhan aktiva yang tinggi akan meningkatkan risiko. Berdasarkan hasil penelitian Kusuma (2016) dan Aji dan Prasetiono (2015) menunjukkan asset growth berpengaruh terhadap beta saham. Hal ini diperkuat dengan penelitian yang dilakukan Chen (2014) dalam Priyanto (2017) menunjukkan bahwa asset growth berpengaruh positif terhadap beta saham. Berdasarkan penjelasan tersebut, maka hipotesis keempat yang diajukan adalah:

$\mathrm{H}_{4}$ : Diduga asset growth berpengaruh positif signifikan terhadap beta saham.

\section{Metode Penelitian}

Metode pengumpulan data dalam penelitian ini adalah dengan metode dokumentasi. Jenis data yang digunakan dalam penelitian ini adalah data dokumenter berupa laporan tahunan. Sumber data adalah data sekunder yaitu data yang diperoleh secara tidak langsung melalui perantara di website www.idx.co.id dan Indonesia Capital Market Directory (ICMD) Sedangkan untuk beta saham diperoleh melalui website www.pefindo.com. Populasi dari penelitian ini adalah perusahaan real estate dan property di Bursa Efek Indonesia. Pengambilan sampel menggunakan metode purposive sampling yaitu teknik penentuan sampel dengan pertimbangan tertentu (Sugiyono, 2018:138) kriteria-kriteria tersebut, yaitu:

1. Perusahaan real estate dan property yang secara konsisten terdaftar dalam Bursa Efek Indonesia tahun 2014-2018.

2. Perusahaan real estate dan property yang konsisten menampilkan data beta saham di PEFINDO tahun 2014-2018. 
3. Perusahaan real estate dan property yang memiliki data lengkap tentang current ratio, debt to equity ratio, return on asset dan asset growth pada tahun 2014-2018 dan tidak pernah delisting.

4. Data return on asset (ROA) dan asset growth tidak boleh negatif.

\section{Definisi Operasional Variabel}

\section{Tabel 1}

Definisi Operasional Variabel

\begin{tabular}{|c|c|}
\hline Variabel $\mathrm{X}$ dan $\mathrm{Y}$ & Rumus \\
\hline Beta & $\begin{array}{l}\text { a. Tahap pertama menghitung return saham dan } \\
\text { indeks pasar di hari rabu dengan interval } \\
\text { pengukuran selama } 4 \text { mingguan dengan } \\
\text { rumus: } \\
\text { b. Melakukan regresi antara return harga saham } \\
\text { dan return indeks pasar untuk periode } 3 \\
\text { tahun terakhir, sehingga mendapatkan nilai } \\
\text { raw beta dengan rumus: } \\
\text { c. Melakukan perhitungan adjusted beta untuk } \\
\text { menormalisasi raw beta agar sesuai dengan } \\
\text { karakteristik beta yang baik yaitu mendekati } \\
\text { 1. Rumus: }\end{array}$ \\
\hline Current ratio $(\mathrm{CR})$ & Current Ratio $=\frac{\text { Aktiva Lancar }}{\text { Hutang Lancar }}$ \\
\hline Debt to equity ratio (DER) & $\mathrm{DER}=\frac{\text { Long term debt }}{\text { Shareholder Equity }}$ \\
\hline Return on asset (ROA) & $R O A=\frac{\text { Laba setelah pajak }}{\text { Total Asset }} \times 100$ \\
\hline Asset growth & Asset Growth $=\frac{\text { Total Asset }(t)-\text { Total Asset }(t-1)}{\text { Total Asset }(t-1)}$ \\
\hline
\end{tabular}

Sumber: Data sekunder, diolah 2019

\section{Regresi Linier Berganda}

Model yang digunakan dalam regresi berganda untuk melihat pengaruh current ratio, debt to equity ratio, return on asset dan asset growth terhadap beta saham adalah:

$$
\mathbf{Y}=\alpha+\mathbf{X}_{1}+\mathbf{X}_{2}+\mathbf{X}_{3}+\mathbf{X}_{4}+\mathbf{e}
$$


Keterangan:

$$
\begin{array}{ll}
\mathrm{Y} & =\text { Beta saham sebagai variabel dependen } \\
\alpha & =\text { Konstanta } \\
& =\text { Koefisien regresi model } \\
\mathrm{X}_{1} & =\text { Current ratio sebagai variabel independen } \\
\mathrm{X}_{2} & =\text { Debt to equity ratio sebagai variabel independen } \\
\mathrm{X}_{3} & =\text { Return } \text { on asset } \text { sebagai variabel independen } \\
\mathrm{X}_{4} & =\text { Asset } \text { growth } \text { sebagai variabel independen } \\
\mathrm{e} & =\text { Error term (kesalahan residu) }
\end{array}
$$

Berdasarkan data sampel perusahaan real estate dan property yang terdaftar di Bursa Efek Indonesia (BEI) pada tahun 2014-2018 yang memenuhi kriteria sampel sebanyak 14 perusahaan namun setelah melalui proses outlier menghasilkan sampel sebanyak 10 perusahaan. Daftar sampel perusahaan dapat dilihat pada Tabel 2 sebagai berikut:

Tabel 2

Daftar Sampel Perusahan Setelah Outlier

\begin{tabular}{|c|l|c|c|c|}
\hline No & \multicolumn{1}{|c|}{ Nama Emiten } & Kode & Berdiri & Go Public \\
\hline 1 & $\begin{array}{l}\text { PT. Agung Podomoro Land } \\
\text { Tbk }\end{array}$ & APLN & $30 / 07 / 2004$ & $11 / 11 / 2010$ \\
\hline 2 & PT. Alam Sutera Realty Tbk & ASRI & $3 / 11 / 1993$ & $18 / 12 / 2007$ \\
\hline 3 & PT. Sentul City Tbk & BKSL & $16 / 04 / 1993$ & $28 / 07 / 1997$ \\
\hline 4 & PT. Bumi Serpong Damai Tbk & BSDE & $16 / 01 / 1984$ & $6 / 6 / 2008$ \\
\hline 5 & PT. Ciputra Development Tbk & CTRA & $22 / 10 / 1981$ & $28 / 03 / 1994$ \\
\hline 6 & PT. Duta Anggada Realty Tbk & DART & $30 / 12 / 1983$ & $8 / 5 / 1990$ \\
\hline 7 & PT. Intiland Development Tbk & DILD & $10 / 6 / 1983$ & $4 / 9 / 1991$ \\
\hline 8 & PT. Duta Pertiwi Tbk & DUTI & $29 / 12 / 1972$ & $2 / 11 / 1994$ \\
\hline 9 & PT. Modernland Realty Tbk & MDLN & $8 / 8 / 1983$ & $18 / 01 / 1993$ \\
\hline 10 & PT. Summarecon Agung Tbk & SMRA & $26 / 11 / 1975$ & $7 / 5 / 1990$ \\
\hline
\end{tabular}

Sumber: Data sekunder, diolah 2019

\section{Hasil dan Pembahasan}

\section{Deskripsi Statistik}

Penentuan sampel menggunakan metode purposive sampling dengan kriteria yang telah ditentukan dalam Tabel 3 sebagai berikut: 
INOBIS: Jurnal Inovasi Bisnis dan Manajemen Indonesia

Volume 03, Nomor 02, Maret 2020

Diah Ayu Shoviana Ranti, Damayanti

Tabel 3

Proses Pemilihan Sampel

\begin{tabular}{|l|c|}
\hline \multicolumn{1}{|c|}{ Kriteria } & Jumlah \\
\hline $\begin{array}{l}\text { Perusahaan real estate dan property yang terdaftar di BEI tahun } \\
\text { 2014-2018. }\end{array}$ & 48 \\
\hline $\begin{array}{l}\text { Perusahaan real estate dan property yang tidak konsisten } \\
\text { melaporkan data beta saham di PEFINDO tahun 2014-2018. }\end{array}$ & $(22)$ \\
\hline $\begin{array}{l}\text { Perusahaan real estate dan property yang memiliki nilai ROA dan } \\
\text { asset growth negatif. }\end{array}$ & $(12)$ \\
\hline Dikeluarkan karena data outlier. & (4) \\
\hline Jumlah sampel akhir. & 50 \\
\hline $\begin{array}{l}\text { Jumlah observasi tahun pengamatan 2014-2018 (5 tahun x } 10 \\
\text { sampel) }\end{array}$ \\
\hline
\end{tabular}

Sumber: Data sekunder, diolah 2019

Data menunjukkan total observasi terdapat 50 data. 50 data tersebut mengalami transformasi data. Transformasi data digunakan karena untuk mengatasi masalah dalam uji asumsi klasik. Masalah uji asumsi klasik yang dihadapi dalam penelitian ini yaitu uji autokorelasi. Uji autokorelasi yang digunakan dalam penelitian ini yaitu run test. Hasil uji autokorelasi sebelum transformasi data menunjukkan tingkat signifikansi 0,000 yang berarti uji autokorelasi tidak lolos karena tingkat signifikansi dibawah 0,05. Setelah melakukan proses transformasi data melalui cochrane orcutt tingkat signifikansi naik menjadi 0,998, namun setelah melakukan proses transformasi data dengan cochrane orcutt terdapat 1 sampel yang hilang. Sehingga total observasi penelitian ini berjumlah 49 sampel.

Berdasarkan hasil pengujian statistik deskriptif dapat diketahui nilai maksimum, nilai minimum, rata-rata (mean) dan standar deviasi dari setiap variabel. Adapun analisis deskriptif variabel dalam penelitian ini dapat dilihat pada Tabel 4.

Tabel 4

Hasil Uji Statistik Deskriptif

\begin{tabular}{|l|r|r|r|r|r|}
\hline & \multicolumn{1}{|c|}{ N } & Minimum & Maximum & Mean & $\begin{array}{c}\text { Std. } \\
\text { Deviation }\end{array}$ \\
\hline LagBeta & 49 & $-0,22$ & 1,28 & 0,3380 & 0,32187 \\
\hline LagCR & 49 & $-151,02$ & 270,19 & 406,597 & $6,404,618$ \\
\hline LagDER & 49 & $-59,46$ & 72,63 & 246,246 & $2,358,910$ \\
\hline LagROA & 49 & $-6,84$ & 14,00 & 10,781 & 374,860 \\
\hline LagAG & 49 & $-40,08$ & 73,85 & 28,063 & $1,484,304$ \\
\hline $\begin{array}{l}\text { Valid N } \\
\text { (listwise) }\end{array}$ & 49 & & & & \\
\hline
\end{tabular}

Sumber: Data sekunder, diolah 2019 


\section{Hasil Uji Asumsi Klasik}

Uji asumsi klasik bertujuan untuk menguji kelayakan model regresi yang digunakan dalam penelitian. Pengujian asumsi klasik diperlukan supaya model regresinya menjadi BLUE (Best Linear Unbias Estimate) sehingga menjadi persamaan linear yang paling baik tanpa adanya bias.

Jumlah observasi yang siap diuji asumsi klasik adalah 50 observasi. Berdasarkan uji asumsi klasik dalam penelitian ini tidak lolos uji autokorelasi. Apabila model regresinya terdapat autokorelasi maka menyebabkan variansi sampel tidak dapat menggambarkan variansi populasi. Model regresi yang dihasilkan juga tidak dapat digunakan untuk menduga nilai variabel dependen dari nilai variabel independen tertentu, koefesien regresinya kurang akurat. Sehingga diperlukan pengobatan dengan tranformasi data menggunakan metode cochrane orcutt. Metode cochrane orcutt dipilih karena koefisien autokorelasi ( $\rho$ ) atau yang disebut dengan istilah "Rho" tidak diketahui, namun jika menggunakan metode cochrane orcutt jumlah obeservasinya berkurang 1, sehingga menjadi 49 observasi.

\section{Uji Multikolonieritas}

Uji multikolonieritas bertujuan untuk menguji apakah model regresi ditemukan adanya korelasi antar variabel independen (variabel bebas). Model regresi yang baik yaitu tidak terjadi korelasi antar variabel independen. Untuk mengetahui ada tidaknya multikolonieritas antar variabel independen yaitu dengan melihat nilai tolerance $\leq 0,10$ dan variance inflation factor (VIF) $\geq 10$ (Ghozali, 2016:103). Hasil uji multikolonieritas dapat dilihat pada Tabel 5 berikut ini:

Tabel 5

Hasil Uji Multikolinieritas

\begin{tabular}{|l|c|c|l|}
\hline Variabel & Tolerance & VIF & \multicolumn{1}{|c|}{ Keterangan } \\
\hline LagCR & 0,831 & 1,203 & $\begin{array}{l}\text { Tidak terjadi } \\
\text { multikolinieritas }\end{array}$ \\
\hline LagDER & 0,840 & 1,191 & $\begin{array}{l}\text { Tidak terjadi } \\
\text { multikolinieritas }\end{array}$ \\
\hline LagROA & 0,842 & 1,188 & $\begin{array}{l}\text { Tidak terjadi } \\
\text { multikolinieritas }\end{array}$ \\
\hline LagAG & 0,908 & 1,101 & $\begin{array}{l}\text { Tidak terjadi } \\
\text { multikolinieritas }\end{array}$ \\
\hline
\end{tabular}

Sumber: Data sekunder, diolah 2019

Nilai tolerance dan VIF pada Tabel 5 menunjukkan bahwa semua variabel bebas (independen) dalam penelitian ini tidak terjadi multikolinieritas. Hal ini ditunjukkan dengan nilai tolerance dari variabel tersebut besarnya $\leq 0,10$ dan variance inflation factor (VIF) $\geq$ 10.

\section{Uji Autokorelasi}

Uji autokorelasi bertujuan menguji apakah dalam model regresi linier ada korelasi antara kesalahan penganggu pada periode $t$ dengan kesalahan penganggu pada periode $t-1$ 
(sebelumnya). Untuk menguji ada tidaknya autokorelasi dapat digunakan uji run test yaitu untuk menguji apakah antar residual terdapat korelasi yang tinggi. Uji run test jika probabilitas lebih besar dari 0,05 maka tidak terjadi autokorelasi (Ghozali, 2016:107). Hasil uji autokorelasi dapat dilihat pada Tabel 6 berikut ini:

\section{Tabel 6}

\begin{tabular}{lc}
\multicolumn{2}{c}{ Hasil Uji Autokorelasi Setelah Cochrane Orcutt } \\
\hline & Unstandardized Residual \\
\hline Asymp. Sig. (2-tailed) & 0,998
\end{tabular}

Sumber: Data sekunder, diolah 2019

Pada Tabel 6 menunjukkan bahwa dengan nilai asymp signifikan 0,925 yang berarti tingkat signifikannya $>0,05$ sehingga dapat disimpulkan bahwa model regresi dalam penelitian ini tidak terjadi autokorelasi.

\section{Uji Heteroskedastisitas}

Uji heteroskedastisitas bertujuan menguji apakah model regresi terjadi ketidaksamaan variance dari residual satu pengamatan ke pengamatan lain. Variance dari residual satu pengamatan ke pengamatan lain tetap, maka disebut homoskedastisitas dan jika berbeda heteroskedastisitas. Model regresi yang baik adalah yang homoskedastisitas atau tidak terjadi heteroskedastisitas (Ghozali, 2016:134). Penelitian ini menggunakan uji glejser untuk menguji ada tidaknya heteroskedastisitas. Uji glejser bertujuan untuk meregres nilai absolut residual terhadap variabel independen. Jika probabilitas signifikansinya $>5 \%$ maka model regresi tidak terjadi heteroskedastisitas dan jika $<5 \%$ terjadi heteroskedastisitas. Hasil uji heteroskedastisitas dapat dilihat pada Tabel 7 berikut ini:

Tabel 7

Hasil Uji Heteroskedastisitas

\begin{tabular}{|l|l|l|}
\hline Variabel & Sig & Keterangan \\
\hline LagCR & 0,614 & $\begin{array}{l}\text { Tidak terjadi } \\
\text { heteroskedastisitas }\end{array}$ \\
\hline LagDER & 0,774 & $\begin{array}{l}\text { Tidak terjadi } \\
\text { heteroskedastisitas }\end{array}$ \\
\hline LagROA & 0,724 & $\begin{array}{l}\text { Tidak terjadi } \\
\text { heteroskedastisitas }\end{array}$ \\
\hline LagAG & 0,513 & $\begin{array}{l}\text { Tidak terjadi } \\
\text { heteroskedastisitas }\end{array}$ \\
\hline
\end{tabular}

Sumber: Data sekunder, diolah 2019

Pada Tabel 7 dapat dilihat bahwa nilai signifikan dari variabel independen $>5 \%$ $(0,05)$. Sehingga dapat disimpulkan bahwa model regresi tidak mengandung adanya heteroskedastisitas. 


\section{Uji Normalitas}

Uji normalitas bertujuan untuk menguji apakah dalam model regresi, variabel pengganggu atau residual memiliki distribusi normal. Jika Asymp. Signifikan > 0,05 berati residual berdistribusi normal. Sebaliknya jika Asymp. signifikansi $<0,05$ berarti residual tidak berdistribusi normal. Untuk menguji ada tidaknya normalitas digunakan analisis statistik yaitu untuk menguji normalitas data setiap data variabel digunakan uji statistik nonparametik kolmogorov smirnov (KS) (Ghozali, 2016:154). Hasil uji normalitas dapat dilihat pada Tabel 8 berikut ini:

\section{Tabel 8}

Hasil Uji Normalitas

\begin{tabular}{cc}
\hline Kolmogorov-Smirnov Z & $\mathbf{0 , 5 4 8}$ \\
\hline Asymp. Sig. (2-tailed) & 0,925 \\
\hline \multicolumn{2}{c}{ Sumber: Data sekunder, diolah 2019}
\end{tabular}

Dari hasil uji normalitas Tabel 8 menunjukkan nilai Asymp. Sig (2-tailed) sebesar 0,925 yang nilainya lebih besar dari 0,05. Dengan demikian model regresi dalam penelitian ini berdistribusi normal.

\section{Hasil Uji Hipotesis}

Dalam pengujian hipotesis untuk model regresi, untuk mengetahui nilai derajat bebas dapat ditentukan dengan rumus $\mathrm{df}=\mathrm{n}-(\mathrm{k}+1)$. Dimana $\mathrm{n}=$ banyaknya sampel yang digunakan, sedangkan k = banyaknya variabel independen. Diperoleh $\mathrm{df}=49-(4+1)=44$. Pengujian hipotesis dengan nilai signifikansi $<0,05$. Dengan demikian dapat disimpulkan nilai $t_{\text {tabel }}$ adalah sebesar 1, 6802. Hasil uji hipotesis dapat dilihat pada Tabel 9

Tabel 9

Hasil Uji Hipotesis

\begin{tabular}{|l|c|c|c|c|l|}
\hline \multicolumn{1}{|c|}{ Variabel } & $\mathbf{B}$ & $\mathbf{t}_{\text {hitung }}$ & $\mathbf{t}_{\text {tabel }}$ & Sig. & Keputusan \\
\hline (Constant) & 0,217 & & & & \\
\hline LagCR & $-0,001$ & $-1,101$ & $-16,802$ & 0,277 & $\mathrm{H}_{1}$ ditolak \\
\hline LagDER & 0,005 & 2,497 & 1,6802 & 0,016 & $\mathrm{H}_{2}$ diterima \\
\hline LagROA & 0,026 & 2,236 & 1,6802 & 0,030 & $\mathrm{H}_{3}$ diterima \\
\hline LagAG & 0,003 & 1,022 & 1,6802 & 0,312 & $\mathrm{H}_{4}$ ditolak \\
\hline
\end{tabular}

Sumber: Data sekunder, diolah 2019

Hasil uji hipotesis pada Tabel 9 dapat dijelaskan sebagai berikut:

1. Hipotesis pertama menyatakan bahwa current ratio $(\mathrm{CR})$ berpengaruh negatif signifikan terhadap beta saham. Dari hasil pengujian pada Tabel 10 tersebut dapat dilihat bahwa nilai koefisien CR adalah negatif sebesar $-0,001$ dan nilai $t_{\text {hitung }}$ sebesar $-1,101$ dan nilai $\mathrm{t}_{\text {tabel }}-1,6802$ pada derajat signifikan $5 \%$. Nilai $t_{\text {hitung }}-1,101>$ nilai $t_{\text {tabel }}-1,6802$ sehingga dapat disimpulkan bahwa $\mathrm{H}_{1}$ yang menyatakan current ratio (CR) berpengaruh negatif signifikan terhadap beta saham ditolak. Hasil pengujian $\mathrm{H}_{1}$ 
menunjukkan bahwa current ratio (CR) berpengaruh negatif tidak signifikan terhadap beta saham pada perusahaan real estate dan property.

2. Hipotesis kedua menyatakan bahwa debt to equity ratio (DER) berpengaruh positif signifikan terhadap beta saham. Dari hasil pengujian pada Tabel 10 tersebut dapat dilihat bahwa nilai koefisien DER adalah positif sebesar 0,005 dan nilai $t_{\text {hitung }}$ sebesar 2,497 dan nilai $t_{\text {tabel }} 1,6802$ pada derajat signifikan $5 \%$. Nilai $t_{\text {hitung }} 2,497>$ nilai $t_{\text {tabel }}$ 1,6802 sehingga dapat disimpulkan bahwa $\mathrm{H}_{2}$ yang menyatakan debt to equity ratio (DER) berpengaruh positif signifikan terhadap beta saham diterima. Hasil pengujian $\mathrm{H}_{2}$ menunjukkan bahwa debt to equity ratio (DER) berpengaruh positif signifikan terhadap beta saham pada perusahaan real estate dan property.

3. Hipotesis ketiga menyatakan bahwa return on asset (ROA) berpengaruh positif signifikan terhadap beta saham. Dari hasil pengujian pada Tabel 10 tersebut dapat dilihat bahwa nilai koefisien ROA adalah positif sebesar 0,026 dan nilai $t_{\text {hitung }}$ sebesar 2,236 dan nilai $t_{\text {tabel }} 1,6802$ pada derajat signifikan $5 \%$. Nilai $t_{\text {hitung }} 2,236>$ nilai $t_{\text {tabel }}$ 1,6802 sehingga dapat disimpulkan bahwa $\mathrm{H}_{3}$ yang menyatakan return on asset (ROA) berpengaruh positif signifikan terhadap beta saham diterima. Hasil pengujian $\mathrm{H}_{3}$ menunjukkan bahwa return on asset (ROA) berpengaruh positif signifikan terhadap beta saham pada perusahaan real estate dan property.

4. Hipotesis keempat menyatakan bahwa asset growth (AG) berpengaruh positif signifikan terhadap beta saham. Dari hasil pengujian pada Tabel 10 tersebut dapat dilihat bahwa nilai koefisien $\mathrm{AG}$ adalah positif sebesar 0,003 dan nilai $t_{\text {hitung }}$ sebesar 1,022 dan nilai $t_{\text {tabel }} 1,6802$ pada derajat signifikan $5 \%$. Nilai thitung $1,022<$ nilai tabel 1,6802 sehingga dapat disimpulkan bahwa $\mathrm{H}_{4}$ yang menyatakan asset growth (AG) berpengaruh positif signifikan terhadap beta saham ditolak. Hasil pengujian $\mathrm{H}_{4}$ menunjukkan bahwa asset growth (AG) berpengaruh positif tidak signifikan terhadap beta saham pada perusahaan real estate dan property.

\section{Hasil Uji Determinasi}

Uji determinasi menunjukkan seberapa besar variabel-variabel independen yang ada di dalam model dapat menerangkan variasi variabel dependen. Hasil uji determinasi terlihat pada Tabel 10

\section{Tabel 10}

Hasil Uji Determinasi

\begin{tabular}{|c|c|c|c|c|}
\hline Model & $\mathbf{R}$ & $\begin{array}{c}\mathbf{R} \\
\text { Square }\end{array}$ & $\begin{array}{c}\text { Adjusted } \\
\text { R Square }\end{array}$ & $\begin{array}{c}\text { Std. Error of } \\
\text { the Estimate }\end{array}$ \\
\hline 1 &, $550^{\mathrm{a}}$ &, 302 &, 239 &, 28088 \\
\hline
\end{tabular}

Sumber: Data sekunder, diolah 2019

Hasil Tabel 10 menunjukkan nilai adjusted $\mathrm{R}^{2}$ sebesar 0,239 . Hal ini berarti bahwa variabel current ratio, debt to equity ratio, return on asset dan asset growth mampu menjelaskan variabel dependen (beta saham) sebesar 23,9\% sedangkan 76,1\% dijelaskan oleh variabel lain yang tidak masuk dalam model penelitian ini. 
INOBIS: Jurnal Inovasi Bisnis dan Manajemen Indonesia

Volume 03, Nomor 02, Maret 2020

Diah Ayu Shoviana Ranti, Damayanti

\section{Pembahasan}

Berdasarkan hasil analisis data tersebut dapat dibahas beberapa hal sebagai berikut:

\section{Pengaruh Current Ratio terhadap Beta Saham}

Hasil pengujian hipotesis pertama menunjukkan bahwa current ratio berpengaruh negatif tidak signifikan terhadap beta saham pada perusahaan real estate dan property, sehingga $\mathrm{H}_{1}$ ditolak. Artinya jika current ratio mengalami kenaikan maka akan berpengaruh sangat kecil pada penurunan beta saham. Begitu pula sebaliknya jika current ratio mengalami penurunan maka akan berpengaruh sangat kecil pada kenaikan beta saham. Current ratio yang tinggi menunjukkan bahwa perusahaan memiliki kemampuan untuk melunasi kewajibannya yang telah jatuh tempo. Coryaina (2013:27) dalam Laraswati, dkk (2018) menjelaskan bahwa current ratio yang tinggi akan memperkecil risiko kegagalan perusahaan dalam memenuhi kewajiban jangka pendeknya terhadap kreditur. Peningkatan current ratio berpengaruh terhadap beta saham yaitu jika current ratio perusahaan semakin baik, perusahaan akan mampu melunasi kewajiban jangka pendeknya dan otomatis beta saham perusahaan akan rendah.

Hasil penelitian ini sesuai dengan teori risk dan return karena secara rasional semakin likuid perusahaan (perusahaan memiliki kinerja baik dan memiliki peluang untuk bekerja sama dengan kreditor), semakin kecil juga risikonya (Hartono, 2017:480). Current ratio tinggi (current asset > current liabilities) maka semakin rendah risiko yang akan ditanggung investor jika akan berinvestasi pada sekuritas perusahaan tersebut. Alasan current ratio tidak berpengaruh terhadap beta saham karena perusahaan real estate dan property karena current ratio yang tinggi menunjukkan bahwa perusahaan memiliki aset lancar yang banyak untuk membayar utang jangka pendeknya. Namun rasio current ratio yang tinggi belum tentu perusahaan dikatakan baik karena rasio current ratio yang tinggi dapat terjadi karena kurang efektifnya manajemen persediaan dan kas. Artinya perusahaan memiliki aset lancar atau kas yang banyak akan tetapi tidak dimanfaatkan dengan baik, kas yang seharusnya dimanfaatkan untuk kegiatan investasi ataupun ekspansi dibiarkan sehingga kas tersebut tidak berputar dan mengakibatkan perusahaan memiliki risiko keuangan. Hasil penelitian ini sesuai dengan hasil penelitian yang dilakukan oleh Aji dan Prasetiono (2015) bahwa current ratio berpengaruh negatif tidak signifikan terhadap beta saham.

\section{Pengaruh Debt to Equity Ratio terhadap Beta Saham}

Hasil pengujian hipotesis kedua menunjukkan bahwa debt to equity ratio berpengaruh positif signifikan terhadap beta saham pada perusahaan real estate dan property, sehingga $\mathrm{H}_{2}$ diterima. Artinya, jika debt to equity ratio mengalami kenaikan maka akan berpengaruh pada kenaikan beta saham. Begitu pula sebaliknya jika debt to equity ratio mengalami penurunan maka akan berpengaruh pada penurunan beta saham. Nilai debt to equity ratio yang tinggi mengidentifikasi bahwa perusahaan memiliki kelebihan utang (over-leverage) dan harus mencari jalan untuk mengurangi utang tersebut. Penggunaan utang yang relatif tinggi akan menimbulkan beban bunga dan angsuran pokok pinjaman yang harus dibayar sehingga laba perusahaan akan turun. Hal ini akan berdampak pada penurunan dividen yang akan meningkatkan risiko kegagalan perusahaan dalam mengembalikan utang sehingga menyebabkan kebangrutan pada perusahaan dan sebaliknya (Gitman dan Zutter (2014) dalam Priyanto (2017). Hasil penelitian ini sesuai dengan teori CAPM yaitu tingkat keuntungan 


\section{Diah Ayu Shoviana Ranti, Damayanti}

yang disyaratkan investor akan dipengaruhi oleh risiko yang akan ditanggung investor pada kondisi pasar yang seimbang. Risk dan return mempunyai hubungan positif. Semakin besar return yang diharapkan oleh investor akan semakin besar pula risiko yang harus ditanggung oleh perusahaan.

Leverage mempunyai hubungan positif terhadap beta (Hartono, 2017:480). Debt to equity ratio yang tinggi merupakan sinyal yang buruk bagi investor karena menunjukkan bahwa perusahaan mengalami kesulitan dalam membayar utang yang besar sehingga risiko yang dihadapi perusahaan juga besar. Hal tersebut akan mengurangi minat para investor dalam menginvestasikan dananya di suatu perusahaan. Hasil penelitian ini sesuai dengan hasil penelitian yang dilakukan oleh Zeinora (2015), Kurniawan dan Mawardi (2018) dan Laraswati, dkk (2018) yang menunjukkan bahwa debt to equity ratio berpengaruh positif signifikan terhadap beta saham.

\section{Pengaruh Return on Asset terhadap Beta Saham}

Hasil pengujian hipotesis ketiga menunjukkan bahwa return on asset berpengaruh positif signifikan terhadap beta saham pada perusahaan real estate dan property, sehingga $\mathrm{H}_{3}$ diterima. Artinya, jika return on asset mengalami kenaikan maka akan berpengaruh pada kenaikan beta saham. Begitu pula sebaliknya jika return on asset mengalami penurunan maka akan berpengaruh pada penurunan beta saham. Hasil penelitian ini sesuai dengan teori CAPM yaitu tingkat keuntungan yang disyaratkan investor akan dipengaruhi oleh risiko yang akan ditanggung investor pada kondisi pasar yang seimbang. Risk dan return mempunyai hubungan positif. Semakin besar return yang diharapkan oleh investor akan semakin besar pula risiko yang harus ditanggung oleh perusahaan.

Ang (1997) dalam Kurniawan dan Mawardi (2018) menyatakan bahwa semakin besar nilai return on asset, maka semakin efektif suatu perusahaan dalam menggunakan aktiva yang dimiliki untuk menghasilkan laba setelah pajak. Tingginya nilai return on asset suatu perusahaan menunjukkan semakin besar keuntungan yang diperoleh perusahaan, keuntungan yang besar tersebut akan menarik minat dan harapan investor untuk berinvestasi di suatu perusahaan dengan tingkat pengembalian (return) yang tinggi. Hasil penelitian ini sesuai dengan hasil penelitian yang dilakukan oleh Kustini dan Pratiwi (2011) dalam Priyanto (2017) dan Oktodinata (2015) yang menunjukkan bahwa return on asset berpengaruh positif terhadap beta saham.

\section{Pengaruh Asset Growth terhadap Beta Saham}

Hasil pengujian hipotesis keempat menunjukkan bahwa asset growth berpengaruh positif tidak signifikan terhadap beta saham pada perusahaan real estate dan property, sehingga $\mathrm{H}_{4}$ ditolak. Artinya, jika asset growth mengalami kenaikan maka akan berpengaruh sangat kecil pada kenaikan beta saham. Begitu pula sebaliknya jika asset growth mengalami penurunan maka akan berpengaruh sangat kecil pada penurunan beta saham.

Semakin tinggi tingkat asset growth perusahaan menunjukkan bahwa perusahaan sedang melakukan ekspansi. Apabila ekspansi ini mengalami kegagalan maka akan meningkatkan beban perusahaan untuk menutup pengembalian biaya ekspansi yang pada akhirnya akan menyebabkan nilai perusahaan itu menjadi kurang prospektif. Apabila kurang prospektif maka menyebabkan para investor menjual sahamnya di perusahaan tersebut karena minat dan harapan para pemodal turun. Hal ini menyebabkan perubahan return saham yang besar yang berakibat pada beta saham perusahaan yang besar (Parmono, 2001 dalam Aji dan 


\section{Diah Ayu Shoviana Ranti, Damayanti}

Prasetiono, 2015). Hasil penelitian ini sesuai dengan teori risk dan return. Alasan asset growth tidak berpengaruh terhadap beta saham karena asset growth diproksikan dengan total aset. Perusahaan dengan tingkat asset growth yang tinggi menunjukkan bahwa perusahaan memiliki kelebihan aset namun tidak dimanfaatkan dengan baik sehingga terjadi pengganguran aset, sehingga perusahaan tidak mampu membayar biaya ekspansi dan risiko gagal bayar semakin tinggi. Hasil penelitian ini sesuai dengan hasil penelitian yang dilakukan oleh Oktodinata (2015) yang menunjukkan bahwa asset growth berpengaruh positif tidak siginifikan terhadap beta saham.

\section{Simpulan, Keterbatasan dan Saran}

Berdasarkan pemaparan hasil penelitian yang dilakukan pada bab sebelumnya, maka dapat diambil simpulan sebagai berikut:

A. Variabel current ratio berpengaruh negatif tidak signifikan terhadap beta saham pada perusahaan real estate dan property. Hal tersebut menunjukkan jika current ratio mengalami kenaikan maka akan berpengaruh sangat kecil pada penurunan beta saham. Begitu pula sebaliknya jika current ratio mengalami penurunan maka akan berpengaruh sangat kecil pada kenaikan beta saham.

B. Variabel debt to equity ratio berpengaruh positif signifikan terhadap beta saham pada perusahaan real estate dan property. Hal tersebut menunjukkan jika debt to equity ratio mengalami kenaikan maka akan berpengaruh pada kenaikan beta saham. Begitu pula sebaliknya jika debt to equity ratio mengalami penurunan maka akan berpengaruh pada penurunan beta saham.

C. Variabel return on asset berpengaruh positif signifikan terhadap beta saham pada perusahaan real estate dan property. Hal tersebut menunjukkan jika return on asset mengalami kenaikan maka akan berpengaruh pada kenaikan beta saham. Begitu pula sebaliknya jika return on asset mengalami penurunan maka akan berpengaruh pada penurunan beta saham.

D. Variabel asset growth berpengaruh positif tidak signifikan terhadap beta saham pada perusahaan real estate dan property. Hal tersebut menunjukkan jika asset growth mengalami kenaikan maka akan berpengaruh sangat kecil pada kenaikan beta saham. Begitu pula sebaliknya jika asset growth mengalami penurunan maka akan berpengaruh sangat kecil pada penurunan beta saham.

Pada penelitian ini, peneliti mengalami keterbatasan yang menghambat hasil penelitian agar sesuai dengan hipotesis yang diajukan. Keterbatasan penelitian ini adalah sebagai berikut:

A. Keterbatasan penelitian ini adalah penelitian ini hanya menggunakan variabel current ratio, debt to equity ratio, return on asset dan asset growth untuk mengetahui pengaruh terhadap beta saham, sedangkan beta saham mungkin dipengaruhi oleh faktor-faktor lain di luar penelitian ini seperti dividend payout ratio, asset size, earning variability dan accounting beta.

B. Adanya keterbatasan waktu dan yang lainya, peneliti hanya melakukan penelitian selama lima tahun terakhir yaitu pada periode 2014-2018 sehingga kurang mencerminkan keadaan perusahaan yang sebenarnya. 
INOBIS: Jurnal Inovasi Bisnis dan Manajemen Indonesia

Volume 03, Nomor 02, Maret 2020

Diah Ayu Shoviana Ranti, Damayanti

Beberapa saran yang dapat peneliti ajukan berdasarkan penelitian ini adalah:

A. Penelitian selanjutnnya disarankan dapat menambah faktor lain yang dapat mempengaruhi harga saham seperti faktor fundamental antara lain: dividend payout ratio, asset size, earning variability, dan accounting beta.

B. Penelitian selanjutnya disarankan menambah periode tahun penelitian.

\section{Daftar Pustaka}

Aji, Rio Satriyo dan Prasetiono, 2015, “Analisis Faktor-Faktor yang Mempengaruhi Risiko Sistematis (Beta) Saham pada Perusahaan Manufaktur yang Terdaftar di Bursa Efek Indonesia (BEI) Periode 2009-2014”, Diponegoro Journal of Management, Vol. 4, No. 4, 2015, ISSN: 2337-3792.

Chen, Ming, 2014, Analisis Pengaruh Perekonomian Makro dan Mikro yang berpengaruh pada Risiko Sistematis Saham, Vol 3, No. 2, Palembang.

Fahmi, Irham, 2011, Analisis Laporan Keuangan, Jakarta: Salemba Empat.

Ghozali, Imam, 2016, Aplikasi Analisis Multivariate dengan Program IBM SPSS 23, Edisi 8, Badan Penerbit Undip, Semarang.

Hanafi, Mamduh dan Abdul Halim, 2016, Analisis Laporan Keuangan, Edisi Kelima, KUPP STIM YKPN, Yogyakarta.

Hartono, Jogiyanto, 2017, Teori Portofolio dan Analisis Investasi, Edisi Kesebelas, BPFE, Yogyakarta.

Hermawan, Hengki, 2018, "Analisis Keuangan yang Mempengaruhi Beta Saham pada Perusahaan Manufaktur Sektor Keramik Porselen dan Kaca yang Terdaftar di Bursa Efek Indonesia Periode 2010-2014”, Jurnal Disrupsi Bisnis, Vol. 1, No. 1, Juli 2018.

Hery, 2016, Analisis Laporan Keuangan, Edisi Pertama, Grasindo, Jakarta.

Jazuli, Muhammad dan Rini Setyo Witiastuti, 2016, "Determinan Beta Saham Perusahaan Real Estate dan Property di BEI", Management Analysis Journal, ISSN:2252-6552.

Kasmir, 2018, Analisis Laporan Keuangan, Edisi Ke-11, Grafindo Persada, Depok.

Kusuma, Indra Lila, 2016, "Pengaruh Asset Growth, Debt to Equity Ratio, Return on Equity, Total Asset Turn Over dan Earning per Share terhadap Beta Saham Perusahaan yang Masuk dalam Kelompok Jakarta Islamic Index (JII) Tahun 2013-2015”, Jurnal Riset Akuntansi dan Keuangan, Vol. IV, No. 2, 2016.

Kurniawan, Ainur Rofiq dan Imron Mawardi, 2018, "Pengaruh Variabel Akuntansi Perusahaan terhadap Risiko Beta Saham Perusahaan yang Tercatat di Jakarta Islamic Index Periode 2012-2016", Jurnal Ekonomi Syariah Teori dan Terapan, Vol. 5, No. 9, September 2018, ISSN:787-799.

Laraswati, Dewi, Akbar Yusuf dan Fitriningsih Amalo, 2018, "Pengaruh Faktor Fundamental (Current Ratio, Return on Asset, Return on Equity, Total Asset Turn Over, Debt to Equity Ratio, dan Asset Growth) terhadap Beta Saham Syariah di Bursa Efek Indonesia", Jurnal Akuntansi, Vol. 5, No. 2, Mei 2018.

Oktodinata, Primanda, 2015, "Pengaruh Dividend Payout Ratio, Return On Asset, Financial Leverage, Assets Growth dan Struktur Modal terhadap Beta Saham”, Jurnal Skripsi Fakultas Ekonomi Universitas Maritim Raja Ali Haji, Vol. 2, No. 1, 2015.

Purbawisesa, Annisa dan Sampurno, R. Djoko, 2016, "Analisis Pengaruh Return On Asset, Dividend Payout Ratio, Asset Growth, Debt to Equity Ratio dan Operating Leverage terhadap Risiko Sistematis", Diponegoro Journal of Management, Vol. 5, No. 3, 2016, ISSN:2337-3792. 
Priyanto, Sugeng, 2017, "Pengaruh Asset Growth, Leverage dan Earning Variability terhadap Beta Saham pada Perusahaan Jakarta Islamic Indeks di Bursa Efek Indonesia", Jurnal Ekonomika dan Manajemen, Vol. VI, No.1, ISSN: 2252-6226.

Sugiyono, 2018, Metode Penelitian Kuantitatif, Edisi Pertama, ALFABETA, CV, Bandung.

Sugiyono, 2017, Metode Penelitian dan Pengembangan, Edisi Ketiga, ALFABETA, Bandung.

Tim Penyusun, 2018, Buku Pedoman Penyusunan Skripsi, STIE YPPI, Rembang.

Pefindo, Beta Stock, Online. https://www.pefindo.com/pageman/page/beta-saham.html, 12 Oktober 2019

Saham Oke, Sektor Property dan Real Estate, Online. https://www.sahamoke.net/emiten/sektor-property-real-estate/sub-sektor-propertyrealestate/, 12 Oktober 2019

Yulia dan Pohan, Hotman T, 2015, "Faktor-Faktor Fundamental yang Mempengaruhi Beta Saham pada Perusahaan Non-Keuangan yang Terdaftar di BEI", Jurnal Magister Akuntasi Trisakti, Vol. 2, No. 2, September 2015, ISSN:2339-0859.

Zainora, 2015, "Pengaruh_Debt to Equity Ratio, Return on Asset, Price Book Value dan Price Earning Ratio terhadap Beta Saham", Journal of Applied Business and Economics, Vol. 2, No. 1, September 2015. 